\title{
The potential of vernacular materials to the sustainable building design
}

\author{
J. Fernandes, R. Mateus \& L. Bragança \\ C-TAC Research Centre, University of Minho, Guimarães, Portugal
}

\begin{abstract}
Vernacular architecture embodies a plurality of constraints from places where it belongs, in which the use of local materials and techniques is one of the main features. When compared with industrially-produced materials, vernacular materials have low environmental impacts, being an alternative for sustainable construction. The increasing use of new industrially-produced and standardized materials led to the homogenization of the different used construction approaches, and spawned a universal architecture that in many cases is out of the environment context and is very dependent on energy and other resources. This paper addresses the relation between Portuguese vernacular architecture and locally sourced materials, relating them with the territory lithology, agricultural crops and the climate. To assess the contribution of these materials for sustainability, a comparison with industrial materials at level of environmental indicators was established. This paper highlights the advantages of using local materials and techniques as a factor of local socio-economic development.
\end{abstract}

\section{INTRODUCTION}

The use of local materials and techniques of construction is one of the most relevant features of vernacular architecture, being an identitary factor of regional differentiation.

With the Industrial Revolution, and later with the Modern Movement, the increasing use of new industrially-produced and standardized materials led to the homogenization of the different used construction approaches, until then dependent on available local materials. Their wide dissemination meant that the use of these materials became predominant and traditional techniques and materials fell into disuse. Modern architecture, based on the use of industrially-produced materials with a low thermal resistance, especially large glass surfaces, has made buildings extremely vulnerable to outdoor temperature fluctuations and with a high level of dependence on air-conditioning systems to ensure conditions of indoor comfort (Montaner 2001; Graça 2000), representing a substantial energy consumption. Beyond this, industrially-produced materials require a high energy-intensity and have considerable environmental impacts, while natural materials such as timber have positive impacts in the overall life-cycle assessment (Mota et al. 2012).

In Portugal, it has been estimated for a conventional building (with a lifetime of 50 years) that the embodied energy in building materials is about $10-15 \%$ of the total energy consumed during operation phase (Mateus et al. 2007). Additionally, the study carried out by Mota et al. 2012 has shown that materials like ceramic tiles, concrete and alkyd paint had the major environmental impacts during overall building life-cycle.

On the other hand, using alternative materials and techniques, like the vernacular ones (lime, adobe, vaulted ceilings, etc.), the total embodied energy of a building can be significantly reduced, as well as environmental impacts (Venkatarama Reddy \& Jagadish 2003; Shukla et al. 2009; SanzCalcedo et al. 2012).

These issues are particularly relevant for construction industry, one of the largest energyconsuming sectors of the economy, which is responsible for almost a third of all carbon emissions (Ürge-Vorsatz et al. 2007). Moreover, it is one of the largest consumers of natural resourceswith some existing reserves forecasted to last only a few dozen years more (Berge 2009).

Sustainable building projects have to take into account all the different aspects of sustainability (the environmental, the economic, the social and the cultural), and usually have as their goals the following aspects (Mateus et al. 2008): the optimisation of site potential; the preservation of the regional and cultural identity; the minimisation of energy consumption; the protection and conservation of water resources; the use of environmentally friendly materials and products; the provision of a healthy and convenient indoor climate; and the optimisation of operational and maintenance practices. 
Attending to these goals, and knowing that construction materials have considerably environmental impacts, vernacular materials have from sustainability point of view several advantages that should be highlighted.

\section{RESEARCH METHODOLOGY}

The research methodology of this study is based on case studies, using a deductive approach and combining qualitative and quantitative analyses. The research has identified and classified the sustainability principles present in Portuguese vernacular architecture. Thus, this article focuses specifically on the importance of using local materials as well as local construction techniques for sustainable development. Data collection was based mainly on primary and secondary sources. Specifically, the data on vernacular materials and construction techniques was collected from several surveys on popular architecture in Portugal (AAVV 1980; Oliveira \& Galhano 1992; Mestre 2002). To relate the uses of vernacular materials to specific local conditions, several examples were chosen, along the Portuguese territory, and mapped. Moreover, it was established a relation to lithology, climate, agricultural and the tree crops. To assess the contribution of these materials to sustainability, a comparison between some vernacular materials and current industrial materials, in terms of environmental indicators, was carried out.

\section{USE OF LOCAL MATERIALS AND TECHNIQUES}

\subsection{Examples in portuguese vernacular architecture}

Broadly speaking, as far as Portugal is concerned it can be stated that where stone exists people build with this; where there is lack of it, people build with earth, wood or other vegetable materials (Oliveira \& Galhano 1992). The materials used were obtained from the geographical area where the buildings were erected. Even in areas of lithological frontier the examples of constructions that use stone from the neighbouring region are rare, because the scarce economic resources of the population did not allow them to access to materials that were not found locally. Only the wealthiest families, or those with some economic ease, could bear the costs of transporting materials (AAVV 1980). The industrialisation brought the habit of using industrially-produced materials, produced far from building sites, what led to the disuse of local traditional materials and techniques.

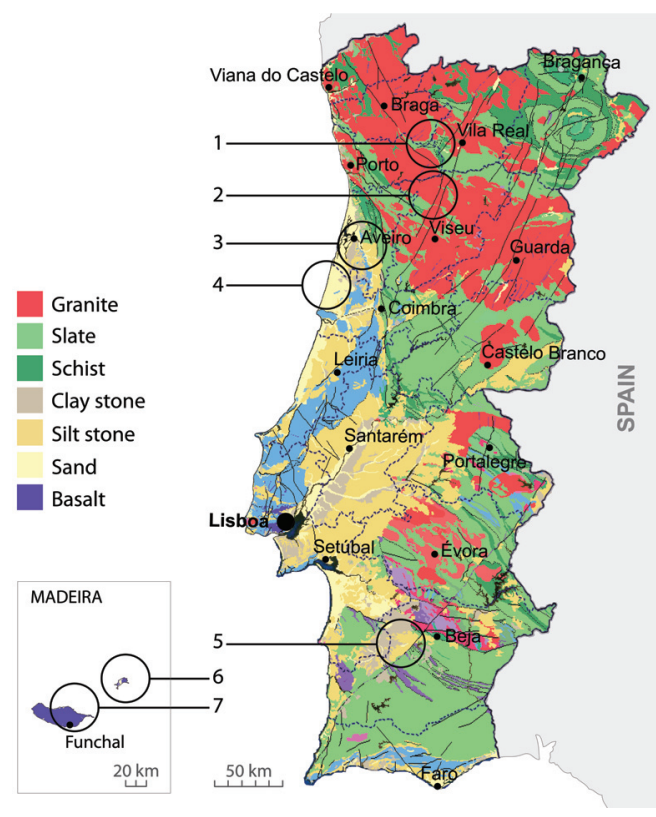

Figure 1. Lithological map of Portugal (Credits: OneGeology-Europe n.d.) and location of the examples.

Even being a small country, Portugal is a territory full of contrasts, not only in climate - with significant variations in air temperature and precipitation (Santos et al. 2002) - but also in the lithological contrast between regions. In Figure 1 and in the following examples it is particularly noticeable that there is an almost perfect correlation between the distribution of the construction materials used and the lithological characteristics of Portuguese territory. To state this fact some examples are highlighted, as follows:

1. In transition zone between schist and granite, constructions reveal the combination of these two materials, either in wall or roofs;

2. In the Montemuro mountains, region of harsh winters and rye crops, roofs were made of straw-a waste from cereal production. This coating ensures simultaneous protection against rain and some thermal insulation;

3. In coastal regions, as the Vouga estuary, where there is no wide availability of stone but where the alluvial soils and clays abound, the buildings are mostly built of adobe;

4. Also in the coast, particularly in the closest constructions to shore - the "palheiros", the wood construction prevails. Forest cover of these areas helps obtaining this material and allows the construction to be almost entirely made of it. For this region, timber construction is the most appropriate in relation to the sandy soil 
and sea moisture (AAVV 1980). This kind of construction has a current potential of prefabrication with an economic maintenance of their coatings piece-by-piece.

5. Rammed earth is the most widespread construction technique in the Alentejo region. In this area the good quality of soil for this type of construction technique is reflected in the profuse use of it (AAVV 1980; Fernandes \& Correia 2005). The high mass that characterizes earthen constructions allows them to respond appropriately to the scorching summer heat of Alentejo. The strong thermal inertia delays the heat flow into the interior.

6. In the island of Porto Santo, the lack of vegetation and wood for construction is the main reason for the use of humblest materials, such as "sand stone" (Mestre 2002). But the element that differentiates these constructions is the roofing coating material called the "salão". This kind of loam from the island is distinguished by its dynamic physical behaviour, perfectly suited to the climate of the island (high temperatures, dryness and low rainfall), i.e., in summer it cracks allowing continuous ventilation; in winter, with the first rains, and due to its natural gum, it quickly aggregates becoming waterproof (Mestre 2002). Besides the highlighted advantages it is also an economical and easy to maintain material (Mestre 2002).

7. In the island of Madeira, in specific locations such as Santana and São Jorge, it is notorious the use of wood in houses built entirely with this material. Their location on the northern slope, along the valleys of dense forest, may be a reason for the more intensive use of this kind of construction.

Analysing the above mentioned examples it is noticeable that the plurality of the Portuguese territory offers a profuse expression of different vernacular building materials. These examples illustrate a close relationship with the characteristics of the sites (lithology, climate, crop and forest cover) where they are used. Materials and techniques used in Portuguese vernacular architecture have potential for contributing positively to the sustainability of the built environment. So there is a need to conduct further studies in order to promote its application in contemporaneity.

\subsection{Advantages of using local materials and techniques on sustainable buildings design}

Vernacular materials and techniques have from the sustainability point of view several advantages that should be promoted. Among these, environmental issues stand out, but there are also social and
Table 1. Embodied energy and Global Warming Potential (cradle-to-gate) of some vernacular and conventional building materials.

\begin{tabular}{lll}
\hline & $\begin{array}{l}\text { Embodied } \\
\text { energy }\end{array}$ & $\begin{array}{l}\text { Global } \\
\text { Warming } \\
\text { Potencial }\end{array}$ \\
\cline { 2 - 3 } Material & $\left(\mathrm{MJ}\right.$ eq. $\left./ \mathrm{m}^{3}\right)$ & $(\mathrm{kg} \mathrm{CO}$ eq./m³) \\
\hline Granite* & 1300 & 26 \\
Timber*(1) & 1058.88 & 57.7 \\
Rammed earth* & 942.5 & 37.7 \\
Straw* & 65 & 0.65 \\
Concrete & 1449.63 & 264 \\
Steel (sections) & 182286 & 2035800 \\
Brick, perforated & 4245 & 357 \\
Ceramic tiles & 22185 & 1167 \\
Roof tiles & 5865 & 535.5 \\
Polystyrene XPS & 3271.13 & 341.25 \\
\hline
\end{tabular}

Sources: Bragança \& Mateus 2011; *Berge 2009. Notes: (1) Sawn timber, air dried, including planning processes.

economical benefits. In this sense, it is pertinent to highlight some of the advantages of using certain types of vernacular materials in opposition to current industrially-produced ones (Table 1).

\subsubsection{Environmental advantages}

Generally, the most relevant environmental advantages related to local materials are: no need of transportation; less energy intensive production process and consequently lower embodied energy and $\mathrm{CO}_{2}$ emissions; they are natural materials, often organic, renewable and biodegradable, with a life cycle from "cradle to cradle"; low environmental impact during maintenance operations. A brief comparison regarding environmental aspects between local and industrially-produced materials is presented in Table 1. To compare environmental impacts resulting from the use of materials in construction systems, the total weight of each material must be quantified in advance.

In the underneath paragraphs, some advantages related to specific materials and techniques used in Portuguese vernacular architecture will be presented and discussed.

Thatch/straw-Waste material resulting from the production of rye. It has been used for a long time in regions with this type of crop. It has the advantages of being a natural material, fully biodegradable, low cost, with a good performance against natural elements, such as rain and snow, as well as insulation properties. There is no specific data on thermal conductivity of the straw applied in roofing solutions, the most common application in vernacular architecture, but it is possible to extrapolate this value from the straw bales $(\mathrm{a} 60 \mathrm{~cm}$ 
thick straw bale has a U-value bounded between 0.12 to $0.09 \mathrm{~W} / \mathrm{m}^{2}{ }^{\circ} \mathrm{C}$ ) (Sassi 2006). The disadvantages of straw, mainly in relation to ceramic tiles insulated with extruded polystyrene are: lower fire resistance; and the need for periodic replacement, even considering the reduced cost of this process. In a sustainable building design, it is possible to use this material in contemporary applications and it has good potential for integration with new materials (Yuan \& Sun 2010).

Rammed earth and adobe-These are two good examples of traditional materials made from soil of the construction site, an abundant resource with reduced environmental impacts associated with its extraction (Sassi 2006). Although most of these constructions are in developing countries, the number of these constructions in developed countries has been increasing thanks to the importance given to sustainable construction (Pacheco-Torgal \& Jalali 2012). Earthen architecture, due to its multiple advantages, continues to make sense in the Portuguese context, especially in areas that traditionally have used this material. Some advantages, among many others, are (Wargocki et al. 1999; Gutiérrez et al. 2005): i) strong thermal inertia ii) ability to influence the quality of indoor air, since it has no VOCs associated; iii) hygroscopic inertia, ie, acting as moisture regulators, retaining it in the appropriate proportions to human health (from 40 to $60 \%$ ), contributing to the stability of the indoor microclimate; iv) low embodied energy; v) low carbon emissions and low environmental impact; vi) low cost material; vii) if performed on raw earth it can be reused indefinitely. In the case of adobe constructions, the study of Shukla et al. (2009), a life-cycle assessment (LCA) of a dwelling mainly built in adobe, concluded that for every $100 \mathrm{~m}^{2}$ of built area adobe housing presented an embodied energy of $475 \mathrm{GJ}$, while the conventional housing had $720 \mathrm{GJ}$.

The disadvantages commonly associated with earthen architecture can be seen from a different perspective, namely: these buildings may have great durability; there are numerous cases with hundreds of years and some over 1000 years old that have reached to the 21st century (Pacheco-Torgal \& Jalali 2012); and despite the need for periodic maintenance to ensure its durability this does not entail a high cost.

Research in this field shows that there is still potential to improve the properties of these materials, as exemplified in the study conducted by Pereira \& Correia da Silva (2012). The authors demonstrated the possibility of improving the thermal resistance of rammed earth walls, in order to comply with the Portuguese regulations for thermal performance, without changing their environmental characteristics, by adding a mixture of granulated cork.

Vaulted ceilings - the practice of building using this technique began to disappear in the first third of the 20th century with the increasing use of reinforced concrete slabs. However, recent studies have disclosed that the use of this technique in traditional vaulted brick ceilings is more sustainable than conventional concrete slabs. In a life cycle analysis of the traditional vaulted ceilings, compared with concrete slabs, require for their construction $75 \%$ less energy, produce $69 \%$ less $\mathrm{CO}_{2}$, have a similar or lower average cost and produce less $171 \%$ of waste (Sanz-Calcedo et al. 2012). The same study states that it is a technique that meets the current requirements of sustainability and can be integrated into current construction techniques, being very economic and functional. The lessons learned from this study come to support that vaults continue to be viable in contemporary construction, in addition to the significant contribution to the sustainability of the building stock. The need for more skilled workmanship is presented as a disadvantage but, taking into consideration that the cost of these structures is not superior to conventional concrete slabs, the allocation of structure cost to manpower appears to be an added value. In order to have this technique properly valued and spread it is necessary that its advantages are disseminated among all construction stakeholders and that new professionals can be trained in the implementation of this technique.

Loam roofs - In the island of Porto Santo there are some examples of vernacular constructions that use loam roof systems. This system is locally identified as "salão". Loam is composed, among others, by a mixture of sand, clay, silt, and organic matter. It has many advantages, such as the fact of having a dynamic behaviour, enabled by weather changes, and being an economic material (Mestre 2002). Additionally, it is an environmentally friendly material and although there is no detailed published data about this technique, by affinity with other materials such as rammed earth and adobe, it is possible to say that it has low embodied energy. Its application in the construction requires no special treatment and its maintenance is carried out with the simple application of another layer of loam. This technique is currently in disuse on the island, where the use of ceramic tile is dominant (Mestre 2002). In order to protect and reintegrate this technique, future economic and feasibility studies are needed to scientifically sustain the suitability of its use in the specific context of Porto Santo.

Timber-this construction material is omnipresent in Portuguese vernacular architecture. Depending on local availability its use in construction 
ranges from occasional use as structural element to the integral construction of housing. As for the latter, "palheiros" and the houses of Santana are noteworthy examples. The advantages of wooden construction today, which were already visible in the vernacular examples, are: it is renewable, biodegradable and recyclable; it requires little processing to be used in construction; and it allows prefabrication - which contributes to reduce construction waste. Depending on the method of construction we can also consider the chance of a more efficient and economic maintenance, with the possibility to replace piece-by-piece, as in "palheiros", without changing the structure of the building. Since it requires low processing to be applied in construction it has a relatively low embodied energy. The study of Coelho et al. (2012) on the life cycle assessment of a wooden house, reveals the importance of using local resources of raw materials and local production to reduce transportation needs that affect the environmental performance of this kind of construction. Having in mind the abovementioned advantages of wood construction, this construction system should be encouraged, especially in places where this is suitable. The incentives to wood construction can also be an incentive for sustainable forest management. This one needed to tackle climate change that is enforcing new challenges to forest preservation, including the maintenance of viable ecosystems to ensure the productivity and retention of forest environmental services (Silva 2007). The planning of forestation still has several environmental advantages, including the ability to increase carbon sequestration, help to regulate the climate, control soil erosion, retain water in the soil and create conditions for the development of biodiversity (fauna and flora) (Marques 2008).

\subsubsection{Social and economic advantages}

To achieve a truly sustainable development it is also necessary to take into account the social and economic dimensions. In the construction sector it is critical to have the ability to understand these three dimensions. Edum-Fotwe \& Price (2009) divided the process of building in three levelsurban, buildings and materials - and for the latter defined a set of social parameters to be considered for improving the sustainability of the built environment, such as: employment; health; safety; wellbeing; education and training skills; and culture/heritage. Analyzing, even superficially, the potential benefits of using vernacular materials, we can conclude that it fits all the social parameters defined in the abovementioned study.

Regarding employment, several studies report the great need of more and skilled workmanship as a disadvantage of traditional construction techniques. But taking into account that the direct cost of these materials and structures is often inferior to that of conventional building systems, the allocation of the structure cost to manpower seems to be an advantage. The distribution of the income among more stakeholders is socially fairer than just allocating it to the price of a material. The local production of materials is not only economically cheaper, as it also enables creating jobs for unemployed people (Sanya 2007 cited in Pacheco-Torgal \& Jalali 2012). Additionally, the need for skilled workmanship leads to education and training on these vernacular building systems, contributing not only to improve the qualifications of the several construction stakeholders but also to preserve and continue a local heritage and cultural legacy. The education in vernacular building systems is also crucial for politicians, sociologists and economists who make decisions about the built environment (Oliver 2006).

The fact that these materials came from the same local climatic conditions where they were applied has the following advantages: greater adaptability, economy and increased durability (Singh et al. 2011).

In matters of health, advantages are mainly related to the fact that these materials are of natural origin, with low toxicity, no volatile organic compounds, some of them with properties capable of regulating the temperature and indoor air quality (Berge 2009), as referred in the example of earthen architecture.

In terms of economy, Goodman (1968 cited in Berge 2009) argues that an industry of ecological construction must have their production units near the place of consumption, using local renewable resources, focusing on processes that require little energy and produce reduced pollution. Furthermore he argues that decentralization can increase corporate decision-making centres and have a clearer idea of the context in which they labour, especially relationships between decision-makers and local resources. In this sense Oliver (2006) also argues that the discourse on sustainability is too oriented at the cities scale, requiring the implementation of decentralization policies in economies that contribute to the regeneration of rural areas. The redevelopment of these areas could be a way to stop the expansion of cities.

In order to promote and implement this kind of intent it is necessary to involve the local authorities. Each site has its own idiosyncrasies that must be taken into consideration in the definition of specific policies adapted to its context (Dumreicher \& Kolb 2008). Supporting sustainable local development means also preserving a cultural heritage of construction knowledge inherent to regions. 
Materials are essential for construction but they cause significant environmental impacts, especially those whose production is high energy intensive. In the past, due to lack of technological solutions capable of producing more advanced materials and to transport them over long distances, materials used in vernacular constructions had low-tech profile and were restricted to those available on sites. These were mostly natural, had low processing, low embodied energy and consequently reduced environmental impacts.

In contrast, today's technology allows the production of hi-tech materials, available on global scale, although usually requiring an energy-intensive processing. In addition, centralized production of these materials implies large energy requirements for transportation, from the extraction point of raw materials to the distribution of finished products.

Taking into consideration that traditional materials are closely related to local conditions and have significantly less environmental impacts and embodied energy than current construction materials, their use means a potential to reduce impacts throughout the life-cycle of buildings, in a "cradleto-grave" approach. Thus, to achieve sustainability, architecture should seek integration between tradition and contemporaneity, using the best of both in technologies and materials. Beyond the environmental issues, promoting the use of local materials may have a positive impact on local social and economical developments.

Nevertheless, there is still a lack of information regarding Portuguese context on this subject. Therefore, more studies are needed to interpret and understand the best vernacular techniques so that they can be improved and transposed to contemporaneity, in order to be scientifically validated, giving them credibility and encouraging their use among the stakeholders in the building sector. It is up to designers to use their creativity to improve and adapt these techniques to new functional building requirements.

\section{REFERENCES}

AAVV, 1980. Arquitectura Popular em Portugal 2nd ed., Lisboa: Associação dos Arquitectos Portugueses.

Berge, B., 2009. The Ecology of Building Materials 2nd ed., Oxford: Elsevier.

Bragança, L. \& Mateus, R., 2011. Avaliação do Ciclo de Vida dos Edificios-Impacte Ambiental de Soluções Construtivas, iiSBE Portugal.

Coelho, A., Branco, J. \& Gervásio, H., 2012. Life-cycle assessment of a single-family timber house. In R. Amoêda et al., eds. BSA 2012: 1st International
Conference on Building Sustainability Assessment. Porto: Greenlines Institute for Sustainable Development, pp. 533-542.

Dumreicher, H. \& Kolb, B., 2008. Place as a social space: fields of encounter relating to the local sustainability process. Journal of environmental management, 87(2), pp.317-28.

Edum-Fotwe, F.T. \& Price, A.D.F., 2009. A social ontology for appraising sustainability of construction projects and developments. International Journal of Project Management, 27(4), pp.313-322.

Fernandes, M. \& Correia, M. eds., 2005. Arquitectura de terra em Portugal/Earth architecture in Portugal, Lisboa: Argumentum.

Goodman, P., 1968. People or Personnel: Decentralising and the Mixed Systems, New York: Vintage.

Graça, J.M., 2000. Arquitectura e clima, por quê? Arquitectura e Vida.$^{\circ}$ 4, pp.60-62.

Gutiérrez, S., Mújica, J. \& Jiménez, Y., 2005. Arquitectura de tierra, alternativa de edificación sustentable. In Terra em seminário, IV Seminário Ibero-Americano de Construção em Terra. Argumentum \& Escola Superior Gallaecia, pp. 152-155.

Marques, L., 2008. O papel da madeira na sustentabilidade da construção. Universidade do Porto.

Mateus, R. et al., 2007. Sustainability Assessment of an Energy Efficient Optimized Solution. In M. Santamouris \& P. Wouters, eds. 2nd PALENC Conference and 28th AIVC Conference on Building Low Energy Cooling and Advanced Ventilation Technologies in the 21st Century. Heliotopos: Heliotopos Conferences, pp. 636-640.

Mateus, R., Bragança, L. \& Koukkari, H., 2008. Sustainability Assessment and Rating of Portuguese Buildings. In G. Foliente et al., eds. Proceedings of the 2008 World Sustainable Conference (SB08). Melbourne: ASN Events Pty, pp. 959-966.

Mestre, V., 2002. Arquitectura Popular da Madeira, Lisboa: Argumentum.

Montaner, J.M., 2001. Depois do movimento moderno: Arquitectura da segunda metade do séc. XX., Barcelona: Editorial Gustavo Gili, S.A.

Mota, L., Mateus, R. \& Bragança, L., 2012. The contribution of the maintenance phase for the environmental lifecycle impacts of a residential building. In R. Amoêda et al., eds. BSA 2012: 1st International Conference on Building Sustainability Assessment. Porto: Greenlines Institute for Sustainable Development, pp. 603-612.

Oliveira, E.V. \& Galhano, F., 1992. Arquitectura Tradicional Portuguesa, Lisboa: Publicações Dom Quixote.

Oliver, P., 2006. Built to Meet Needs: Cultural Issues in Vernacular Architecture, Oxford: Architectural Press, Elsevier.

OneGeology-Europe, OGC Web Map Service (WMS) Available at: http://onegeology-europe.brgm.fr/ [Accessed April 23, 2013].

Pacheco-Torgal, F. \& Jalali, S., 2012. Earth construction: Lessons from the past for future eco-efficient construction. Construction and Building Materials, 29(null), pp.512-519.

Pereira, J.P.B. \& Correia da Silva, J.J., 2012. Contributo para a melhoria do desempenho térmico das paredes de taipa. In Congresso Construção 2012-4. ${ }^{\circ}$ Congresso Nacional. Coimbra: Universidade de Coimbra. Faculdade de Ciências e Tecnologia. 
Santos, F.D., Forbes, K. \& Moita, R. eds., 2002. Climate change in Portugal. Scenarios, Impacts and Adaptation Measure-SIAM Project, Lisbon: Gradiva.

Sanya, T., 2007. Living earth. The sustainability of earth architecture in Uganda. The Oslo school of architecture and design.

Sanz-Calcedo, J.G., Luna, M.F. \& Soriano, R.C., 2012. Evaluation of the efficiency to use sustainable classical techniques on the modern construction. In R. Amoêda et al., eds. BSA 2012: 1st International Conference on Building Sustainability Assessment. Porto: Greenlines Institute for Sustainable Development, pp. 667-675.

Sassi, P., 2006. Strategies for Sustainable Architecture, London: Taylor \& Francis Ltd.

Shukla, A., Tiwari, G.N. \& Sodha, M.S., 2009. Embodied energy analysis of adobe house. Renewable Energy, 34(3), pp.755-761.

Silva, J.S. ed., 2007. Árvores e Florestas de Portugal Vol. 7, Floresta e Sociedade-Uma história em comum.,
Lisboa: Público, Comunicação Social, SA e Fundação Luso-Americana para o Desenvolvimento.

Singh, M.K., Mahapatra, S. \& Atreya, S.K., 2011. Solar passive features in vernacular architecture of NorthEast India. Solar Energy, 85(9), pp.2011-2022.

Ürge-Vorsatz, D. et al., 2007. Mitigating CO 2 emissions from energy use in the world's buildings. Building Research \& Information, 35(4), pp.379-398.

Venkatarama Reddy, B.. \& Jagadish, K.., 2003. Embodied energy of common and alternative building materials and technologies. Energy and Buildings, 35(2), pp.129-137.

Wargocki, P. et al., 1999. Perceived air quality, sick building syndrome (SBS) symptoms and productivity in an office with two different pollution loads. Indoor Air, 9(3), pp.165-179.

Yuan, T.-Q. \& Sun, R.-C., 2010. Cereal Straw as a Resource for Sustainable Biomaterials and Biofuels, Elsevier. 